\title{
Is a Fully Established Arbuscular Mycorrhizal Symbiosis Required for Bioprotection of Pisum sativum Roots against Aphanomyces euteiches?
}

\author{
Sophie Slezack, Eliane Dumas-Gaudot, Michel Paynot, and Silvio Gianinazzi \\ Laboratoire de Phytoparasitologie INRA/CNRS, CMSE, Institut National de la Recherche Agronomique, BV \\ 1540, 21034 Dijon cédex, France \\ Accepted 20 October 1999.
}

\begin{abstract}
Bioprotection of pea roots against Aphanomyces euteiches by the arbuscular mycorrhizal fungus $G$. mosseae was demonstrated to depend on a fully established symbiosis. This was related with induction of mycorrrhiza-related chitinolytic enzymes. Possible mechanisms implicated in bioprotection are discussed.
\end{abstract}

Additional keywords: chitinase, chitosanase, Glomus mosseae, pea mutants.

Pea (Pisum sativum L.) root rot caused by Aphanomyces euteiches is one of the most serious pea diseases in several countries (Mauffras et al. 1997; Papavizas and Ayers 1974). The difficulties in controlling this disease have prompted a search for biological alternatives (Parke et al. 1991; Rao et al. 1995). Mycorrhizal plants are able to overcome biotic stresses (Azcón-Aguilar and Barea 1996; St. Arnaud et al. 1995). Rosendahl (1985) reported first that A. euteiches infection of pea roots was reduced in plants colonized by the arbuscular mycorrhizal (AM) fungus Glomus fasciculatum. However, molecular mechanisms governing bioprotection by AM fungi are poorly understood (Azcón-Aguilar and Barea 1996; Hooker et al. 1994; St. Arnaud et al. 1995). Furthermore, the conditions allowing its expression are ambiguous (Caron 1989; St. Arnaud et al. 1995). While several studies reported a reduction in damages caused by a pathogenic fungus after coinoculation, or post-inoculation, with an AM fungus (Caron et al. 1986; Krishna and Bagyaraj 1983), others showed that only a well-established AM infection could protect plants (Cordier et al. 1996,, 1998; Dassi et al. 1998; Rosendahl 1985). Among molecular changes related to AM symbiosis formation, the induction of additional chitinase and chitosanase isoforms was reported (Dumas-Gaudot et al. 1994; Pozo et al. 1996, 1998; Slezack et al. 1996). Both categories of enzymes are generally known to be involved in plant resistance (El Ouakfaoui and Asselin 1992; Graham and Sticklen 1994).

Our objective was to determine whether bioprotection of pea against $A$. euteiches requires root pre-colonization by AM fungi. This was achieved by comparing two pea genotypes

Corresponding author: Eliane Dumas-Gaudot; Telephone: (33)-3-80-6931-26; Fax: (33)-3-80-69-32-63; E-mail: dumas@epoisses.inra.fr differing in their ability to form symbiosis (Duc et al. 1989) and by spraying plants with gibberellic acid $\left(\mathrm{Ga}_{3}\right)$, a phytohormone known to inhibit arbuscule formation inside the root cells (El Ghachtouli et al. 1996).

Plantlets from seeds of both the wild-type cv. Frisson $\left(\mathrm{Myc}^{+} \mathrm{Nod}^{+}\right)$and the $\mathrm{Myc}^{-1}$ pea mutant $\left(\mathrm{Myc}^{-} \mathrm{Nod}^{-}\right)$in which the AM fungus develops only appressoria were used. Control and 15-day-old Glomus mosseae (BEG 12)-inoculated plants were infected or not with $10^{5} \mathrm{~A}$. euteiches zoospores (Slezack et al. 1999) and harvested 10 days later. Half of control and $G$. mosseae-inoculated plantlets were sprayed daily with $\mathrm{Ga}_{3} 10^{-4}$ $\mathrm{M}$ starting at 4 days after transplanting. Bioprotection was estimated by measuring the root rot disease index (Rao et al. 1995) and quantifying the pathogen in roots by enzyme-linked immunosorbent assay (Slezack et al. 1999). Mycorrhization was estimated following Trouvelot et al. (1986). Two different experiments were carried out with nine repetitions of one plant per pot for each treatment. Statistical analyses were done according to a split-split plot design. No statistical difference was found between the two experiments. Chitinase and chitosanase activities were analyzed after separation in isoelectrofocusing ( $\mathrm{pH} 3.5$ to 9.5; Amersham Pharmacia Biotech, Orsay, France) (Pan et al. 1991) and in sodium dodecyl sulfatepolyacrylamide gel electrophoresis (Grenier and Asselin 1990), respectively. All electrophoresis experiments were conducted at least two times.

A protective effect expressed as a reduction in disease index that is positively correlated with the amount of pathogen detected in planta (Slezack et al. 1999; Kraft and Boge 1994) was demonstrated in mycorrhizal cv. Frisson roots (Table 1). These results are in agreement with those of Rosendahl (1985). The $\mathrm{Myc}^{-1}$ pea mutant, which is as susceptible as the wild type to infection with $A$. euteiches (Gianinazzi-Pearson et al. 1996), was not protected by $G$. mosseae pre-inoculation (Table 1). The pathogenic infection does not seem to alter either mycorrhizal parameters in cv. Frisson (Fig. 1A) or appressoria formation in $\mathrm{Myc}^{-1}$ (Fig. 1B). In cv. Frisson, treatment with $\mathrm{Ga}_{3}$ led to a drastic decrease in mycorrhizal colonization together with an inhibition of arbuscules (Fig. 1A). This was accompanied by the suppression of bioprotection (Table 1). Exogenous application of $\mathrm{Ga}_{3}$ had no effect on appressoria formation in the $\mathrm{Myc}^{-1}$ mutant (Fig. 1B). 
Upon mycorrhization of cv. Frisson, we observed the induction of one basic and four acidic chitinase isoforms (Fig. 2A) and the induction of one chitosanase isoform (Fig. 2B) as reported by Dumas-Gaudot et al. (1994) and Pozo et al. (1998), respectively. As a result of pathogenic infection of both pea genotypes, no chitosanase was detected while the stimulation of constitutive acidic chitinase isoforms together with the induction of three additional ones was observed (Fig. 2A). Two of these acidic chitinase isoforms (Fig. 2A, bars) were also detected in mycorrhizal roots of cv. Frisson. In a situation of bioprotection, mycorrhiza-related chitinase and chitosanase isoforms were maintained (Fig. 2A,B). These isoforms were completely repressed by $\mathrm{Ga}_{3}$ (Fig. 2A) while constitutive or chitinase isoforms induced by one or the other fungus were unaffected (Fig. 2A,B).

By using the $\mathrm{Myc}^{-1}$ pea mutant on the one hand and hormonal treatment on the other, we clearly demonstrate that bioprotection by $G$. mosseae against $A$. euteiches is dependent on a fully established symbiosis with the presence of arbuscules. Furthermore, our results give some information on the mechanisms that could be implicated in this bioprotection. Modifications of mycorrhizosphere were suggested to play a role in bioprotection by AM fungi (Azcón-Aguilar and Barea 1996). Here, the relationship described between AM colonization, reduction of disease symptoms, and pathogen amount strongly suggests that colonization by itself is an essential requirement for bioprotection. Bioprotection of peas against A. euteiches could result from pre-activation of plant defense responses by AM fungi, as suggested by Gianinazzi (1991). Gollotte et al. (1993) showed the activation of several plant defense responses in G. mosseae-inoculated $\mathrm{Myc}^{-1}$ pea mutants. How-

Table 1. Aphanomyces euteiches infection as determined by root rot score rating and enzyme-linked immunosorbent assay (ELISA) in pea roots Glomus mosseae-inoculated or not and sprayed or not with gibberellic acid $10^{-4} \mathrm{M}$

\begin{tabular}{|c|c|c|c|c|}
\hline $\begin{array}{l}\text { Hormonal } \\
\text { treatment }\end{array}$ & Pea genotypes & $\begin{array}{l}\text { Treat- } \\
\text { ments }^{x}\end{array}$ & $\begin{array}{c}\text { Root rot } \\
\text { score } \\
\text { rating }\end{array}$ & $\begin{array}{l}\text { A. euteiches } \\
\text { quant. } \\
\left(\mathrm{mg} \mathrm{ml}^{-1}\right)^{\mathrm{z}}\end{array}$ \\
\hline$-\mathrm{Ga}_{3}$ & $\mathrm{Cv}$. Frisson $\left(\mathrm{Myc}^{+} \mathrm{Nod}^{+}\right)$ & $\mathrm{Nm}$ & $1 \mathrm{a}$ & $0 \mathrm{a}$ \\
\hline$-\mathrm{Ga}_{3}$ & Cv. Frisson $\left(\mathrm{Myc}^{+} \mathrm{Nod}^{+}\right)$ & $\mathrm{Gm}$ & $1 \mathrm{a}$ & $0 \mathrm{a}$ \\
\hline$-\mathrm{Ga}_{3}$ & Cv. Frisson $\left(\mathrm{Myc}^{+} \mathrm{Nod}^{+}\right)$ & Ae & $3.4 \mathrm{~b}$ & $0.107 \mathrm{~b}$ \\
\hline$-\mathrm{Ga}_{3}$ & Cv. Frisson $\left(\mathrm{Myc}^{+} \mathrm{Nod}^{+}\right)$ & $\mathrm{GmAe}$ & $1.9 \mathrm{c}$ & $0.052 \mathrm{c}$ \\
\hline$-\mathrm{Ga}_{3}$ & $\mathrm{Myc}^{-1}\left(\mathrm{Myc}^{-} \mathrm{Nod}^{-}\right)$ & $\mathrm{Nm}$ & $1 \mathrm{a}$ & $0 \mathrm{a}$ \\
\hline$-\mathrm{Ga}_{3}$ & $\operatorname{Myc}^{-1}\left(\mathrm{Myc}^{-} \mathrm{Nod}^{-}\right)$ & $\mathrm{Gm}$ & $1 \mathrm{a}$ & $0 \mathrm{a}$ \\
\hline$-\mathrm{Ga}_{3}$ & $\operatorname{Myc}^{-1}\left(\mathrm{Myc}^{-} \mathrm{Nod}^{-}\right)$ & $\mathrm{Ae}$ & $3.4 \mathrm{~b}$ & $0.118 \mathrm{~b}$ \\
\hline$-\mathrm{Ga}_{3}$ & $\operatorname{Myc}^{-1}\left(\operatorname{Myc}^{-} \operatorname{Nod}^{-}\right)$ & GmAe & $3.2 \mathrm{~b}$ & $0.112 \mathrm{~b}$ \\
\hline$+\mathrm{Ga}_{3}$ & Cv. Frisson $\left(\mathrm{Myc}^{+} \mathrm{Nod}^{+}\right)$ & $\mathrm{Nm}$ & $1 \mathrm{a}$ & $0 \mathrm{a}$ \\
\hline$+\mathrm{Ga}_{3}$ & Cv. Frisson $\left(\mathrm{Myc}^{+} \mathrm{Nod}^{+}\right)$ & $\mathrm{Gm}$ & $1 \mathrm{a}$ & $0 \mathrm{a}$ \\
\hline$+\mathrm{Ga}_{3}$ & Cv. Frisson $\left(\mathrm{Myc}^{+} \mathrm{Nod}^{+}\right)$ & Ae & $3.0 \mathrm{~b}$ & $0.108 \mathrm{~b}$ \\
\hline$+\mathrm{Ga}_{3}$ & Cv. Frisson $\left(\mathrm{Myc}^{+} \mathrm{Nod}^{+}\right)$ & GmAe & $3.0 \mathrm{~b}$ & $0.118 \mathrm{~b}$ \\
\hline$+\mathrm{Ga}_{3}$ & $\mathrm{Myc}^{-1}\left(\mathrm{Myc}^{-} \mathrm{Nod}^{-}\right)$ & $\mathrm{Nm}$ & $1 \mathrm{a}$ & $0 \mathrm{a}$ \\
\hline$+\mathrm{Ga}_{3}$ & $\operatorname{Myc}^{-1}\left(\operatorname{Myc}^{-} \operatorname{Nod}^{-}\right)$ & $\mathrm{Gm}$ & $1 \mathrm{a}$ & $0 \mathrm{a}$ \\
\hline$+\mathrm{Ga}_{3}$ & $\operatorname{Myc}^{-1}\left(\mathrm{Myc}^{-} \mathrm{Nod}^{-}\right)$ & $\mathrm{Ae}$ & $3.2 \mathrm{~b}$ & $0.125 \mathrm{~b}$ \\
\hline$+\mathrm{Ga}_{3}$ & $\operatorname{Myc}^{-1}\left(\operatorname{Myc}^{-} \operatorname{Nod}^{-}\right)$ & $\mathrm{GmAe}$ & $31 \mathrm{~b}$ & $0.113 \mathrm{~b}$ \\
\hline
\end{tabular}

${ }^{\mathrm{x}} \mathrm{Nm}$ (non-mycorrhizal); Gm (G. mosseae-inoculated); Ae (Aphanomyces euteiches-infected); GmAe (G. mosseae pre-inoculated and A. euteiches-infected). Plants were sprayed $\left(+\mathrm{Ga}_{3}\right)$ or not $\left(-\mathrm{Ga}_{3}\right)$ with gibberellic acid $10^{-4} \mathrm{M}$. Infection with A. euteiches was carried out 15 days after inoculation with $G$. mosseae. Plants were harvested 10 days after infection.

${ }^{\mathrm{y}}$ Root rot score rating was determined according to Rao et al. (1995).

${ }^{\mathrm{z}}$ A. euteiches quantification by ELISA carried out following Slezack et al. (1999). Results with the same letter are not significantly different at $P=0.05$ (Newman-Keuls test) ever, these defense responses are not sufficient to protect plants against the pathogen, as reported here. Cordier et al. (1998) demonstrated that induced resistance against Phytophthora parasitica in mycorrhizal tomato roots resulted from both localized defense responses in arbuscule-containing cells and systemic defense responses in non-mycorrhizal parts of mycorrhizal roots. By using $\mathrm{Ga}_{3}$ treatment, we show the connection between the suppression of arbuscules, the nonexpression of mycorrhiza-related chitinolytic isoforms, and the suppression of bioprotection. It is tempting to speculate on the possible involvement of the mycorrhiza-related chitinolytic isoforms in bioprotection. Recently, one of these chitinase isoforms has been partially sequenced, confirming its plant origin (Slezack 1999). To make a full assessment of the involvement of these enzymes in bioprotection, it remains

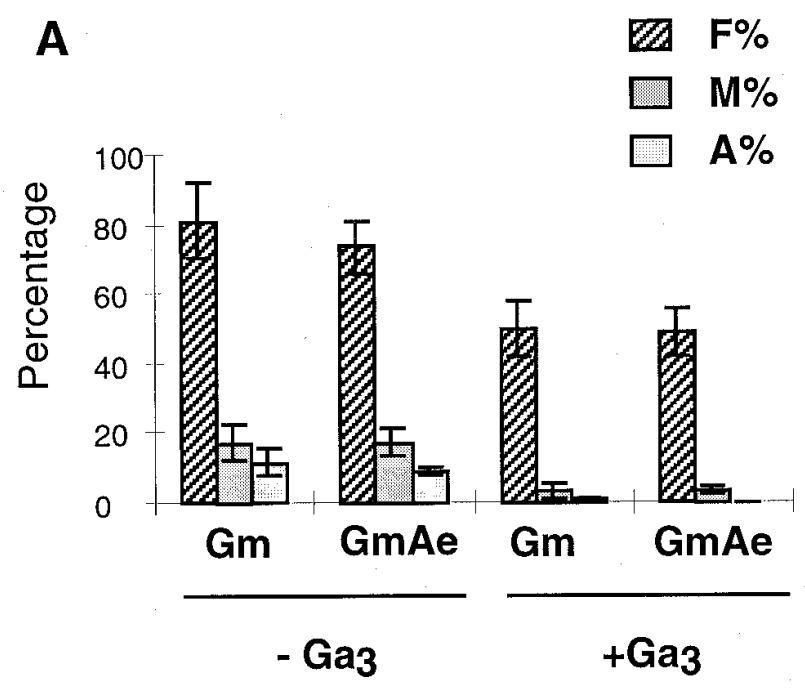

B

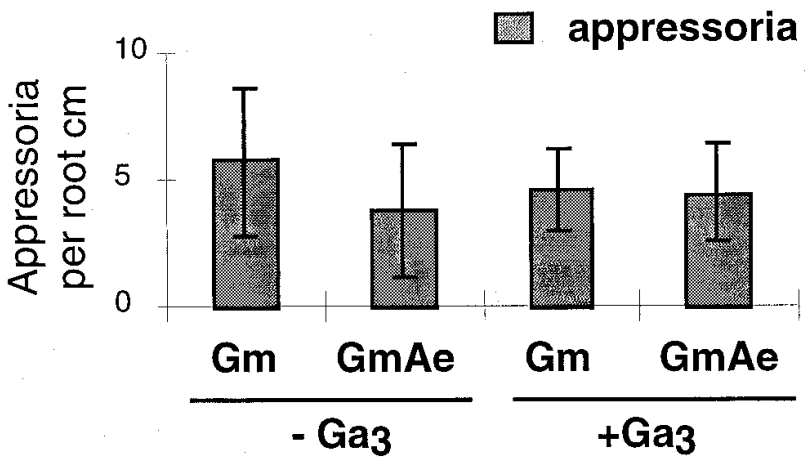

Fig. 1. Development of the arbuscular mycorrhizal fungus Glomus mosseae 25 days after inoculation in the pea wild-type cv. Frisson $\left(\mathrm{Myc}^{+} \mathrm{Nod}^{+}\right)$and the $\mathrm{Myc}^{-1}$ pea mutant $\left(\mathrm{Myc}^{-} \mathrm{Nod}^{-}\right)$. Plants were $G$. mosseae-inoculated $(\mathrm{Gm})$ and G. mosseae pre-inoculated and Aphanomyces euteiches-infected for 10 days $(\mathrm{GmAe})$. They were sprayed $\left(+\mathrm{Ga}_{3}\right)$ or not $\left(-\mathrm{Ga}_{3}\right)$ with gibberellic acid $10^{-4} \mathrm{M}$. A, Mycorrhizal parameters for the wild-type cv. Frisson were determined according to Trouvelot et al. (1986). F\%, frequency of colonization; M\%, intensity of colonization; A\%, arbuscule intensity. $\mathbf{B}$, For the $\mathrm{Myc}^{-1}$ pea mutant, the number of forming appressoria per root $\mathrm{cm}$ was determined. 

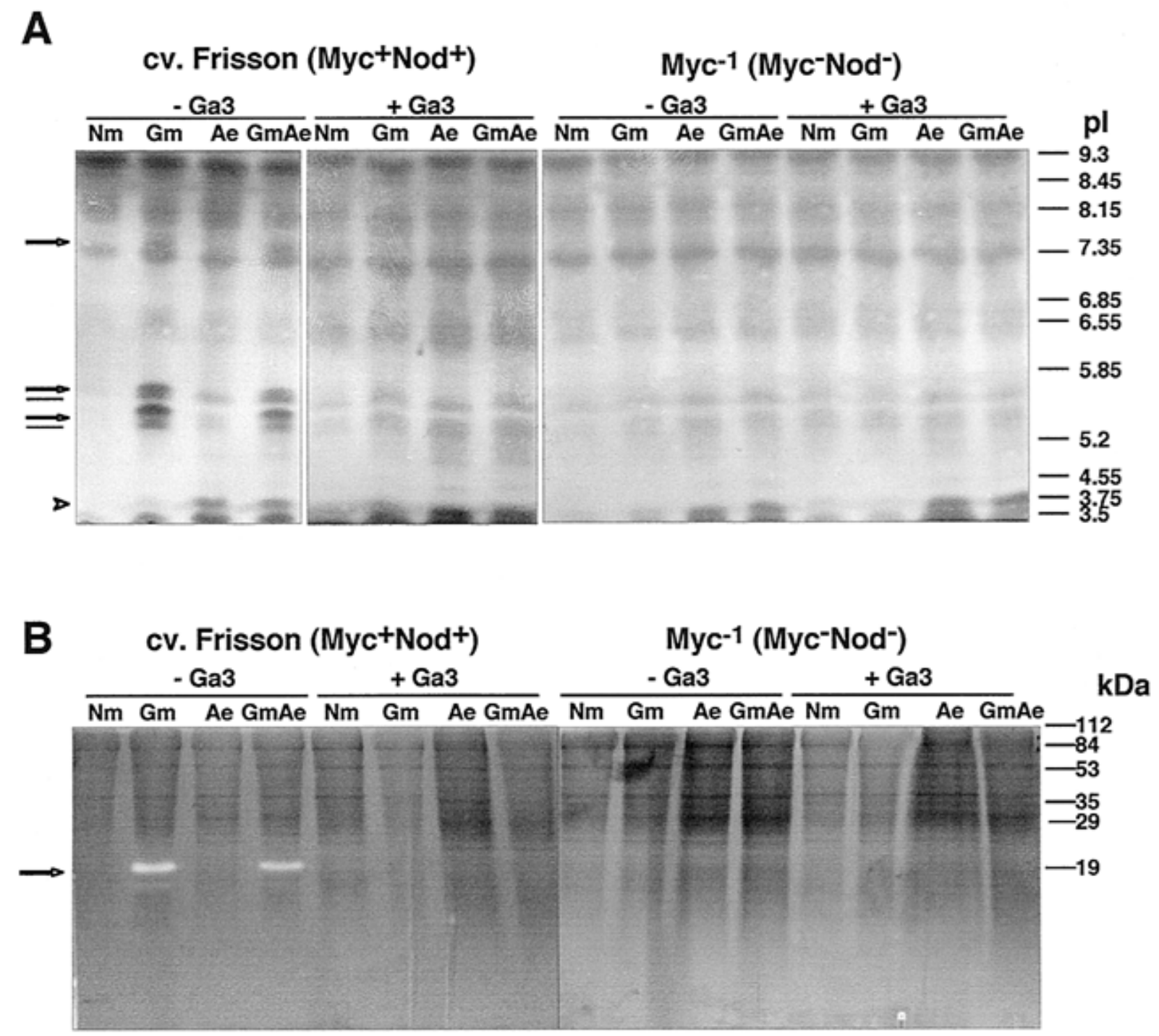

Fig. 2. Analyses of chitinase and chitosanase activities, in the pea wild-type cv. Frisson $\left(\mathrm{Myc}^{+} \mathrm{Nod}^{+}\right)$and the $\mathrm{Myc}^{-1}$ pea mutant $\left(\mathrm{Myc}^{-} \mathrm{Nod}^{-}\right)$after separation by (A) isoelectrofocusing (pH 3.5 to 9.5; Pan et al., 1991) and (B) sodium dodecyl sulfate-polyacrylamide gel electrophoresis (Grenier and Asselin 1990) conditions, respectively. Fifteen micrograms of proteins was loaded in each well. Extracts from nonmycorrhizal (Nm), Glomus mosseae-inoculated $(\mathrm{Gm})$, Aphanomyces euteiches-infected (Ae), and G. mosseae pre-inoculated and A. euteiches-infected $(\mathrm{GmAe})$ pea roots. Plants were sprayed (+Ga $)$ or not $\left(-\mathrm{Ga}_{3}\right)$ with gibberellic acid $10^{-4} \mathrm{M}$. Mycorrhiza-related chitinases and chitosanases are indicated by arrows, A. euteiches-induced chitinase by an arrow head, and chitinases induced by one or the other fungus by bars. On the right, (A) isoelectric point and (B) low molecular weight markers.

to isolate mycorrhiza-related chitinase genes to see whether inhibition of the expression of such genes will have any effect on bioprotection.

\section{ACKNOWLEDGMENTS}

This work was supported in part by UNIP (Union Nationale Interprofessionnelle des Plantes riches en protéines) and by Conseil Régional de Bourgogne. We would like to thank Josette Bonnefoy for technical assistance, Gwënaelle Bestel-Corre for linguistic advice, and Jean-Pierre Caussanel for statistical analyses.

\section{LITERATURE CITED}

Azcón-Aguilar, C., and Barea, J. M. 1996. Arbuscular mycorrhizas and biological control of soil-born plant pathogens - an overview of the mechanisms involved. Mycorrhiza 6:457-464.
Caron, M. 1989. Problématique de l'utilisation des champignons endomycorhiziens comme agents de lutte biologique. Phytoprotection 70: 43-49. Caron, M., Fortin, J. A., and Richard, C. 1986. Effect of inoculation sequence on the interaction between Glomus intraradices and Fusarium oxysporum f. sp. radicis-lycopersici in tomatoes. Can. J. Plant Pathol. 8:12-16.

Cordier, C., Gianinazzi, S., and Gianinazzi-Pearson, V. 1996. Colonisation patterns of root tissues by Phytophthora nicotianae var. parasitica related to reduced disease in mycorrhizal tomato. Plant Soil 185:223-232.

Cordier, C., Pozo, M. J., Barea, J. M., Gianinazzi, S., and GianinazziPearson, V. 1998. Cell defense responses associated with localized and systemic resistance to Phytophthora parasitica induced in tomato by an arbuscular mycorrhizal fungus. Mol. Plant-Microbe Interact. 11: 1017-1028.

Dassi, B., Dumas-Gaudot, E., and Gianinazzi, S. 1998. Do pathogenesisrelated (PR) proteins play a role in bioprotection of mycorrhizal tomato roots towards Phytophthora parasitica? Physiol. Mol. Plant Pathol. 52:167-183. 
Duc, G., Trouvelot, A., Gianinazzi-Pearson, V., and Gianinazzi, S. 1989. First report of non-mycorrhizal plant mutants (myc-) obtained in pea (Pisum sativum L.) and fababean (Vicia faba L.). Plant Sci. 60:215222.

Dumas-Gaudot, E., Asselin, A., Gianinazzi-Pearson, V., Gollotte, A., and Gianinazzi, S. 1994. Chitinases isoforms in roots of various pea genotypes infected with arbuscular mycorrhizal fungi. Plant Sci. 99: 27-37.

El Ghachtouli, N., Martin-Tanguy, J., Paynot, M., and Gianinazzi, S. 1996. First report of the inhibition of arbuscular mycorrhizal infection of Pisum sativum by specific and irreversible inhibition of polyamine biosynthesis or by gibberellic acid treatment. FEBS Lett. 385:189192.

El Ouakfaoui, N., and Asselin, A. 1992. Diversity of chitosanase activity in cucumber. Plant Sci. 85:33-41.

Gianinazzi, S. 1991. Vesicular-arbuscular (endo-) mycorrhizas: cellular, biochemical and genetic aspects. Agric. Ecosyst. Environ. 35:105119.

Gianinazzi-Pearson, V., Dumas-Gaudot, E., Gollotte, A., Tahiri-Alaoui, A., and Gianinazzi, S. 1996. Cellular and molecular defence-related root responses to invasion by arbuscular mycorrhizal fungi. New Phytol. 133:45-57.

Gollotte, A., Gianinazzi-Pearson, V., Giovannetti, M., Sbrana, C., Avio, L., and Gianinazzi, S. 1993. Cellular localization and cytochemical probing of resistance reactions to arbuscular mycorrhizal fungi in a "locus a" myc- mutant of Pisum sativum L. Planta 191:112-122.

Graham, L. S., and Sticklen, M. B. 1994. Plant chitinases. Can. J. Bot. 72:1057-1083

Grenier, J., and Asselin, A. 1990. Some pathogenesis-related proteins are chitosanases with lytic activity against fungal spores. Mol. PlantMicrobe Interact. 3:401-407.

Hooker, J. E., Jaizme-Vega, M., and Atkinson, D. 1994. Biocontrol of plant pathogens using arbuscular mycorrhizal fungi. Pages 191-200 in: Impact of Arbuscular Mycorrhizas on Sustainable Agriculture and Natural Ecosystems. S. Gianinazzi and S. Schüepp, eds. BirkhäuserVerlag, Basel.

Kraft, J. M., and Boge, W. L. 1994. Development of an antiserum to quantify Aphanomyces euteiches in resistant pea lines. Plant Dis. 78: 179-183.

Krishna, K. R., and Bagyaraj, D. J. 1983. Interaction between Glomus fasciculatum and Sclerotium rolfsii in peanut. Can. J. Bot. 61:23492351.

Mauffras, J. Y., Wicker, E., and Sanssene, J. 1997. Les maladies racinaires du pois (1). Perspect. Agricol. 226:68-75.

Pan, S. Q., Ye, X. S., and Kuć, J. 1991. A technique for detection of chitinase, $\beta$-1,3-glucanase, and protein patterns after a single separa- tion using polyacrylamide gel electrophoresis or isoelectrofocusing. Phytopathology 81:970-974.

Papavizas, G. C., and Ayers, W. A. 1974. Aphanomyces species and their root diseases in pea and sugarbeet- a review. U.S. Department of Agriculture, Washington, DC.

Parke, J. L., Rand, R. E., Joy, A. E., and King, E. B. 1991. Biological control of Pythium damping-off and Aphanomyces root rot of peas by application of Pseudomonas cepacia or P. fluorescens to seed. Plant Dis. 75:987-992.

Pozo, M. J., Azcón-Aguilar, C., Dumas-Gaudot, E., and Barea, J. M. 1998. Chitosanase and chitinase activities in tomato roots during interactions with arbuscular mycorrhizal fungi or Phytophthora parasitica. J. Exp. Bot. 49:1729-1739.

Pozo, M. J., Dumas-Gaudot, E., Slezack, S., Cordier, C., Asselin, A., Gianinazzi, S., Gianinazzi-Pearson, V., Azcón-Aguilar, C., and Barea, J. M. 1996. Induction of new chitinase isoforms in tomato roots during interactions with Glomus mosseae and/or Phytophthora nicotianae var. parasitica. Agronomie 16:689-697.

Rao, A., Gritton, E. T., Grau, C. R., and Peterson, L. A. 1995. Aeroponic chambers for evaluating resistance to Aphanomyces root rot of peas (Pisum sativum). Plant Dis. 79:128-132.

Rosendahl, S. 1985. Interactions between the vesicular-arbuscular mycorrhizal fungus Glomus fasciculatum and Aphanomyces euteiches root rot of peas. Phytopathol. Z. 114:31-40.

Slezack, S. 1999. Etude de la bioprotection du pois (Pisum sativum L.) par le champignon mycorhizogène à arbuscules Glomus mosseae visà-vis du champignon pathogène Aphanomyces euteiches. Ph.D. diss. University of Burgundy, Dijon, France.

Slezack, S., Dassi, B., and Dumas-Gaudot, E. 1996. Arbuscular mycorrhiza-induced chitinase isoforms. Pages 339-347 in: Chitin Enzymology. R. A. A. Muzzarelli, ed. Atec Editiony, Senigallia, Italy.

Slezack, S., Dumas-Gaudot, E., Rosendahl, S., Kjoller, R., Paynot, M., Negrel, J., and Gianinazzi, S. 1999. Endoproteolytic activities in pea roots inoculated with the arbuscular mycorrhizal fungus Glomus mosseae and/or Aphanomyces euteiches in relation to bioprotection. New Phytol. 142:517-529.

St. Arnaud, M., Hamel, C., Caron, M., and Fortin, J. A. 1995. Endomycorhizes VA et sensibilité des plantes aux maladies: synthèse de la littérature et des mécanismes d'interaction potentiels. Pages 51-87 in: La symbiose mycorhizienne: état des connaissances. J. A. Fortin, C. Charest and Y. Piché, eds. ORTIS, Frelisghsburg, Québec, Canada.

Trouvelot, A., Kough, J. L., and Gianinazzi-Pearson, V. 1986. Mesure du taux de mycorhization d'un système radiculaire. Recherche de méthodes d'estimation ayant une signification fonctionnelle. Pages 217-221 in: Physiological and Genetical Aspects of Mycorrhizae. V. Gianinazzi-Pearson and S. Gianinazzi, eds. INRA, Dijon, France. 